5

llenan de suspicacia: Martínez de la Torre, Xavier Abril, Martín Adan, Armando Bazán, Esteban Pavletich, Peña Barrenechea, Oquendo de Amat, etc. Por último, tenemos los independientes, que han adoptado una posición espectacular, en momentos difíciles para el Perú, donde se necesita la fuerza de todos ellos dentro de la vida política y social: Antenor Orrego, Jorge Basadre, Luis Alberto Sánchez, Emilio Romero, Eugenio Garro, Alcides Spelucín, para no citar sino a los más representativos.-S E R A F I N D E L M A R.

\title{
Cinema documental para América
}

7 A AMERICA es un hecho de paisaje. Cierto: es el asiento de una jerarquía soberana de paisaje que crean los climas diferentes y en parte la población, rectificadora siempre de la fisonomía del suelo. IberoAmérica constituye, antes que otra cosa, una fiesta de panoramas, reserva para el ojo del Viejo Mundo que ya se cansa de su geografía sobajeada y aprendida. Somos unas pequeñas manchas de hombres - ciudades, aldeas - ceñidas por una porción de tierra bienaventurada, de tierra feliz, que casi anula el hecho humano para dejarlo reducido a hecho geográfico y a suceso extraordinario de la flora y la fauna.

Dice el europeo mirando hacia nuestro Continente: «La Cordillera de los Andes, varias llanuras, costas. $\gg$

Pero la Oordillera no es eso que se enuncia con tanto simplismo. La salvaje empinadura que el europeo mira en rigurosa unidad es un sistema complejo de cumbres baldías, de mesetas amplias, de vertientes y valles longitudinales y trasversales.

En el Anahuac, esta meseta es la más fina estación geológica que pueda concebirse: volcanes de formas depuradísimas, atmósfera de cristal y una elegante vegetación decorativa; hacia el Ecuador forma la famosa avenida de conos volcánicos, una especie de corredor fantástico de bella horizontalidad, asistido en toda su longitud de aquella presencia centauresca; hacia Bolivia se llama puna, su vegetación escasea pero aun abastece ganado. Este es el paisaje de que se enseñorean los rebaños de llamas, vicuñas y alpacas, animales más heráldicos del Continente que las águilas de los escudos, pues no se reproducen en otro cuadro geográfico del mundo.

Después de las mesetas, viene la sierra, zona media entre 
las cumbres y el llano, hermosa en su accidente variado y lugar de ciudades que como el Cuzco peruano quedan ensartadas entre lo espléndido de las alturas y lo jugoso de los bajíos, avizorando ambas zonas vegetales.

Calva en los coronamientos, selva compacta abajo, o sea, Cordillera seca y Cordillera húmeda, como la llaman ios geógrafos, ella ha sido apenas divulgada por la imagen, apenas contada por el grabado: permanece desconocida hasta de sus propias gentes.

Será el cine documental el que dé a nuestras poblaciones el deleite de su montaña madre.

Después de la Cordillera esencial, nuestra América es el llano, llano-selvoso en la cuenca del Amazonas, llano-estepa en Venezuela, llano-pradera en la Pampa argentina, llanojardín hacia el centro de Chile.

El primero, o sea el bosque tropical tipo, se ha quedado tan inédito para el ojo americano como la misma Cordillera. Encerrado en el núcleo del Continente, especie de aurícula y ventrículo suyos, la selva amazónica se halla de tal modo alejada de las costas en que hormiguean las ciudades, que ha sido hojeada en sus especies más próceres sólo por unos cuantos botánicos y la han recorrido en el río máximoúnicamente los bogadores indios.

El cine entrará en esa zona de Génesis, en que todo está nuevo y como untado todavía de la gracia primogénita. De las familias vegetales aristocráticas, no repetidas ni en la selva indostánica ni en la sudanesa, la cinta recogerá lo mismo la masa del follaje que el preciosismo de la flor; los ejemplares de vigor monstruoso darán fotografías individuales que pasen a ser en los libros de Botánica lo que son en las monografías de esculturas los Hércules y los Júpiter antiguos.

Las vistas de conjunto conseguirán presentarnos el hervor vegetal de cauchos, bambúes y lianas, entre los que pasa, en un relámpago azafranado, el jaguar brasilero o el venado del bajío mexicano.

El llano de América es la tierra de la clemencia, ofrecido a la vida humana. La pampa argentina es el más desahogado hogar de hombres que ha entregado nunca el planeta. Monótono y noble, en ninguna farte el árbol aislado tiene más expresión de presencia que asiste. El ombú se humaniza y se vuelve el $\mathrm{Booz}$ de la extensión verde.

El llano domado, el llano a la europea, que la mano hortelana ha vuelto civil, ha hecho institución vigilada y regida, que es el de Chile, probará en la viña perfecta y en la cinta 
de los huertos que existe ya una América de agro a lo italiano y a lo francés, donde la barbarie ha sido trasmutada en suave logro seguro.

La América geológica, vegetal y animal es un bloque, repito, solamente tartamudeado, no dicho, del planeta. Las descripciones de los Humboldt, los Reclus, los Denis y los Bruhnes, se han quedado en los libros de especialidad, y unas por secas, otras por falta de síntesis, no podrán alcanzar nunca a las masas. Será el cine quien las incorpore a la imaginación popular, lo cual no es poco.

El hombre moderno busca tomar posesión del globo, con una avidez que la criatura antigua no conoció. El Asia ha aprovechado de este apetito de conocimiento total, para vindicarse en sus nobles monumentos y expresarse cabalmente en su naturaleza. Nuestra América seguirá al Asia.

El mapa habla únicamente para el geógrafo. Por la carta geográfica siente el niño-y el adulto común que se rezaga en la infancia-una antipatía que yo le conocí en diez años de enseñanza del ramo. No ha podido inventarse cosa más abstracta, más inerte y más lejana, para dar el conocimiento de lo concreto y lo vital. La maravilla de la isla se vuelve una mostacita; el fiordo una rasguñadura en azul; la selva una mancha en verde descolorido; la linea capitana de las montañas, una culebrilla, sin sugerencia alguna. El mapa queda más lejos de la critura de diez años que un problema teológico.

Este mapa pedante y paralítico va a ponerse entero a vivir en el cine, ofrecedor de paisajes vivientes.

Va a dar palabra al alambre de los ríos; va a hacerle la batidura de colores en las masas oceánicas; va a enderezarle galvanizada la serpiente muerta y en círculo de las grandes ciudades.

El mapa servirá como organizador de la muchedumbre de visiones cortadas que el cinema habrá proporcionado. Esa será, y no texto alguno, por perfecto que se logre, la geografía animada que todos venimos pidiendo y que nos hace tanta falta para que el niño considere el mundo la plataforma caliente en la cual se cumple la vida: la vida humana, la animal y la vegetal, no una al lado de la otra, en rayas artificialmente paralelas, sino una trenzada con la otra.

Yo creo que el cine documental verificará nuestra incorporación definitiva en la mente europea, y que será superior como fuerza informativa a toda propaganda escrita, trivial casi siempre o estropeada por la exageración. El dirá 
nuestras excelencias sin necesidad de hipérbole y sin posibilidad de mentirijilla.

El Instituto del Cinema Educacional podrá hacer en nuestro favor lo que no ha realizado institución europea alguna, en el sentido de excitar a las empresas a la divulgación gráfica de nuestro continente; en el de articular los trabajos ya logrados y darles unidad, y en el de purificar, con el solo incremento del cine geográfico e histórico de índole documental, la plaga del cine imbécil o perverso que anega nuestros mercados. No necesitará para lo último combatir a ninguna empresa explícitamente; bastará con que informe a los puebios de América respecto del material disponible de películas con asunto nuestro, con panorama, costumbres e historia nuestras. Los pueblosibero-americanos harán la selección por sí mismos.

Queda para un segundo artículo el examinar el cine documental aplicado a la divulgación de las antiguas civilizaciones de América, tan descleñadas, tan estudiadas a medias y tan apresuradamente avizoradas por el europeo.G A B R I E L A I S T R L.

Exclusivo para Atenea en Chile.

\section{La manía de imitar}

TRENTE a los problemas que se plantearon desde los orígenes de su vida libre, la América Latina atendió más a menudo a buscar ejemplos que soluciones propias.

Nunca se preguntó:

- ¿Qué es necesario hacer?

Fruto de una tradición dogmática, su actividad resultó ante todo memorista, y la interrogación se concretó, más bien, en estas palabras:

$-¿$ ¿ué es lo que hicieron otros?

El sistema-absolutamente contrario al que dió nacimiento en el norte anglo sajón a una actividad poderosa y original-adormeció a los pueblos del sur en una atmósfera sobrecargada de imitaciones. En el orden político, sociológico, artístico, municipal, el ideal supremo fué trasplantar lo que existía en las naciones, en las ciudades o en las almas que admirábamos desde lejos. 